\title{
The Effects of Independent Non-Executive Directors (INED) on Company Performance
}

\author{
Kevin Chi Keung Li \\ The Open University of Hong Kong \\ Agol Wai Ming Ho \\ The Open University of Hong Kong \\ Arnold Hing Chuen Poon \\ The Open University of Hong Kong
}

\begin{abstract}
This paper examines the influence of and relationship between independent non-executive directors (INEDs) and the performance of firms listed on the Hong Kong Stock Exchange (SEHK). Many previous studies argue that INEDs can improve corporate governance and firm performance. However, research in this area is ongoing in different countries and stock exchanges and has produced inconsistent conclusions. The results of this study should help in reviewing the suitability of the current INED standards and whether they can be applied to different firm segments in Hong Kong. The paper aims to help policymakers/regulators determine whether further revision of the current INED policy is necessary. The results can be further investigated and applied to other emerging markets/regions worldwide and may be particularly suitable for regions with many family-controlled and state-owned enterprises.
\end{abstract}

Keywords: independent directors, board structure, company performance

\section{INTRODUCTION}

This study aims to present an overview and analysis of the effects of changes in corporate governance and the emergence of stringent INED requirements for companies in Hong Kong as requested by the SEHK. The study highlights the developments and the main changes in corporate governance, especially those relating to the board of director composition and INED requirements, particularly focusing on the companies listed in Hong Kong.

This study is motivated by the puzzle on why businesses under poor corporate governance perform much worse during times of crisis than the businesses under good governance given corporate governance is a means of protecting minority shareholders from major shareholders (Mitton, 2002).

However, the evidence of any significant relationships between board composition and corporate performance has been inconsistent, especially among studies of the effects of the addition of independent directors (A. Anderson \& Gupta, 2009; Barnhart \& Rosenstein, 1998; Berger \& Bonaccorsi di Patti, 2006; Brown \& Caylor, 2009; Cheung, Thomas Connelly, Limpaphayom, \& Zhou, 2007; J. J. Choi, Park, \& Yoo, 
2007; Doidge, Andrew Karolyi, \& Stulz, 2007; Dong-Sung \& Kim, 2007; Duchin et al., 2010; B. E. Hermalin \& Weisbach, 2003; Jackling \& Johl, 2009), family-dominated boards (C. J. P. Chen \& Jaggi, 2000; DeMott, 2008; Jaggi, Leung, \& Gul, 2009) and board size (Dalton, Daily, Johnson, \& Ellstrand, 1999; Jackling \& Johl, 2009; Yermack, 1996) on business performance. These inconsistent findings and the latest new developments, including analysis of the effects of board composition changes on firm performance based on information cost proxies (Duchin et al., 2010), form the background and theoretical thread of this paper in studying the listed companies in Hong Kong.

Nevertheless, whether the success or failure of many companies around the world or in Hong Kong is actually affected by corporate governance attributes (and their levels), especially in terms of board composition and director changes is subject to question. The findings related to whether corporate governance reforms in statutory regulations or financial reporting are adequate to improve firm performance remain mixed and strongly debated by different researchers worldwide (Erkens, Hung, \& Matos, 2012; Kirkpatrick, 2009; Mitton, 2002). Furthermore, the issue of whether the current corporate governance reforms may better prevent the next financial crisis has been the subject of many investor queries. These debates and queries have influenced to further examine the appropriate corporate-governance-related measures or actions that may finally improve firm performance in the long run.

The self-regulating HKEx amended the Code and its corporate governance report starting from January 2005, replacing the Code in Appendix 14 with the main board listing rules and requesting that the number of mandatory INEDs be increased from two to three (HKEX, 2013b). Since the new stock exchange recommendations changed the INED requirement to one-third of all board directors, this research focuses on the effects of independent directors on business performance due to the controversial conclusions observed in various studies.

Owing to the mixed results of the effects of independent directors on firm performance in the previous studies (no correlation, positive and negative), the effects of independent directors on the performance of different types of listed companies in Hong Kong will be tested. In addition, the study also highlights testing the effects of independent directors on the performance of different classifications of companies listed on the SEHK, including all the HK companies vs. State Owned Enterprises (SOEs) and red chips companies in the subsequent studies.

Two main findings of the study will affect the corporate governance policy-setting process and especially the board composition regulations set forward by the Hong Kong financial authorities and SEHK:

1. Whether the effects of increases in the numbers of independent directors across different company segments in Hong Kong move in the same direction or the same magnitude and

2. Whether further increasing the ratio of independent directors on a board (of which INEDs currently comprise at least one-third) should be reviewed based on other recommendations made by other regulatory authorities or stock exchanges around the world.

Following the introduction in section 1 above, section 2 will discuss the methodology of the research, section 3 will further review the empirical model and data, section 4 will present the result of the study and finally the conclusion will be provided in the last section.

\section{METHODOLOGY}

Based on the literature discussed previously, the overall effects of the relationship between independent directors and firm performance are inconclusive (Bhagat \& Black, 2002; Chin-Jung \& Ming-Je, 2007; Dulewicz \& Herbert, 2004). The effects of INEDs on the performance of companies in Hong Kong may be positive, negative or non-correlated according to these different research reports.

The research framework in this paper is then summarised in the following figure, which includes the period, main question and types of companies involved. 
FIGURE 1

SUMMARY OF THE RESEARCH FRAMEWORK

Period:

Change in mandatory number of INEDs from two to three over the period from 2000 to 2011.

New requirement of one third of board directors in 2012.

Effects on performance of different types of companies in Hong Kong over the period.

Types of companies could be tested if any enhancement of monitoring/increase in performance:

HSI constituent companies

H-share companies(for further reserach)

Red chip companies(for further reserach)

Family- vs non-family controlled companies(for further reserach)

GEM companies (for further reserach)

Cross-listing companies (e.g., US ADR) (for further research)

\section{Firm Performance Measurements and Performance Indicator Selection}

Common measures include stock returns, return on assets (ROA), return on equity (ROE), Tobin's q (to measure firm valuation) and other measures such as economic value added (EVA). These measures are discussed as follows.

\section{Stock Returns}

Stock returns available in and extracted from DataStream are commonly used performance variables in many studies. A stock return is equal to a firm's monthly stock return inclusive of dividends for the security in a month (Smith \& Amoako-Adu, 1999).

Return on Equity (ROE) and Return on Assets (ROA)

Financial analysis involving accounting information can be conducted to determine business performance (K. Palepu, P. Healey, V. Bernard, \& E. Peek, 2007). The value of a firm is determined by its 
profitability and growth. As indicated by K. G. Palepu, P. M. Healey, V. L. Bernard, and E. Peek (2007), overall profitability can be measured initially using a ratio such as ROE, which is equal to net profit divided by shareholder's equity. In the long run, the value of a firm increases if its ROE is greater than the cost of capital employed.

\section{Tobin's $Q$}

Another variable frequently used to measure firm performance is Tobin's q, which is the ratio of the market value of a firm's assets (as measured by the market value of its outstanding stock and debt) to the replacement cost of the firm's assets (Tobin, 1969). Tobin's q is widely used to value a firm in both developing and developed financial markets. The variable shows the financial strength of a firm and serves as a proxy for the firm's performance in a financial market.

\section{Market Value Added (MVA) and Economic Value Added (EVA)}

Market value added (MVA) and EVA are two popular measures of firm performance (Gapenski, 1996). MVA is the difference between a firm's total market value (of debt and equity) at the end of the year, less the cumulative book value of the capital invested in the firm at the end of the same year. MVA reflects the stock market's estimate of the current value of all of the firm's capital investment projects. EVA represents the residual income that remains after all of the costs have been recognised, including the opportunity cost of the equity capital employed. It measures the dollar value of the firm's return in excess of the opportunity cost. EVA depends on both operating efficiency and prudent balance sheet management. Without this efficiency, operating profits are low, and without careful balance sheet management, too many assets and too much capital exist, resulting in higher-than-necessary capital costs (Gapenski, 1996).

\section{Profit Efficiency}

As indicated by Berger and Bonaccorsi di Patti (2006), profit efficiency evaluates how close a firm is to earning the profit that a best-practice firm would earn facing the same exogenous conditions. This has the benefit of controlling for firm-specific factors that are outside the control of management and not part of the agency costs. However, the difficulty involved in evaluating the profit function of an individual business makes it unjustifiable to do so, and it is quite difficult to measure such variables in reality.

\section{EMPIRICAL MODEL AND DATA}

Following the above, as the data included in this study (a large number of cross-sectional units and a few periods) are used to analyse the effects of INEDs on business performance in Hong Kong, changes occur in the dependent and independent variables over time. These kinds of longitudinal data can be referred to as panel data, repeated measures or cross-sectional time-series data (Rabe-Hesketh \& Skrondal, 2008). These panel data were collected prospectively by following the same group of subjects or units over time and followed up on the same occasions, leading to a collected set of balanced (i.e., no missing data in general) panel data (Rabe-Hesketh \& Skrondal, 2012).

These longitudinal data can even be viewed as two-level or clustered data with occasions nested in the subjects so that the subjects become the clusters. These longitudinal data are special in that they are level 1 units or occasions and are ordered in time and not exchangeable, unlike other data such as students nested in schools (Rabe-Hesketh \& Skrondal, 2008).

The different panel data analysis methods are discussed as follows. Different methods are used to handle longitudinal or panel data, including the fixed, random and latest mixed effects models if it is assumed that the data are nested under different groups. Given that the data are in a panel data format, it must be decided whether the fixed or random effects model should be chosen for analysis (Wooldridge, 2010). In this study, the panel data are first subjected to a traditional fixed effects regression.

Using OLS regression to handle panel data can present problems, as the data are clustered and unobserved between-subject heterogeneity can occur, leading to within-subject correlations (Rabe-Hesketh \& Skrondal, 2008). 
Assuming $\mathrm{n}$ observations and $\mathrm{T}$ periods, the basic linear unobserved effects model or framework for the panel data can be written as follows (Greene, 2003; Wooldridge, 2010):

$y_{i t}=\beta x_{i t}+z_{i} \alpha+u_{i t} \quad$ for $t=1,2, \ldots \ldots, T$ and $i=1,2 \ldots \ldots n$

where $\mathbf{y}_{\mathbf{i t}}$ is the dependent variable observed for individual $\mathrm{i}$ at time $\mathrm{t}$. Assume there are $\mathrm{K}$ regressors/independent variables in $\mathbf{x}_{\mathbf{i t}} . \mathbf{Z}_{\mathbf{i}} \boldsymbol{\alpha}$ is the unobserved individual effect, where $\mathbf{z}_{\mathbf{i}}$ contains a constant term and a set of individual or group-specific variables, which may be observed (e.g., race, sex, location) or unobserved (e.g., family or company characteristics). $\mathbf{u}_{\text {it }}$ is the error term.

In the econometrics field, as stated by Greene (2003), there are four model structures including pooled model regression, the fixed effects model, the random effects model and random parameters (a less popular model not covered in this study).

\section{Procedures for Choosing Panel Data Regression Methods}

Finally, determining whether to use the fixed or random effects models does not really matter when the period is large and both methods give almost the same estimates of the parameters. However, the choice is unclear when the number of periods $(\mathrm{T})$ is small but the number of individuals $(\mathrm{N})$ is large (Hsiao, 2003). As this study is similar in nature, with a small $\mathrm{T}$ value but a large $\mathrm{N}$ value, the correct panel regression method should be chosen carefully.

As mentioned previously, with the cross-sectional time series data in mind, a panel data model is fitted. There are two major traditional panel regression methods, including the fixed and random effects models. Hence, the decision to use either method or just OLS regression is subject to certain selection procedures and tests. A decision flowchart is useful in making such a selection. According to Dougherty (2011, p. 527), and the procedures in deciding which panel model should be used are followed in this paper.

In this study all of the available companies in the sample from SEHK listed companies are included (i.e., not a random sample). Hence, the fixed effects model was chosen and used for analysis.

Following the alternative procedures, the random effect regression is run and the result of the LM test is not significant ( $\mathrm{p}$-value $=0.2347$ ). However, the F-test results based on the fixed effects model are significant $(\mathrm{F}$-statistic $=105.39$ and $\mathrm{p}$-value $=0.0000)$. Hence, after considering both approaches it can be concluded that the fixed effects model should be used instead of OLS regression. The fixed effects model is equivalent to imposing firm-specific dummy variables in the regression along with other independent variables (Cordeiro, He, Conyon, \& Shaw, 2013).

The effects of the main independent variable (INED) on the dependent variable (performance) are considered in the following panel regression model.

Performance $_{i t}=\alpha+u_{i t}+\beta_{1} I N E D R_{i t}+\beta_{2} \mathrm{FA}_{i t}+\beta_{3} \mathrm{BS}_{\mathrm{t}}+\beta_{4} \mathrm{DE}_{\mathrm{t}}+\beta_{5} \log \mathrm{TA}_{\mathrm{it}}+\beta_{6} \log \mathrm{Mkt}_{\mathrm{it}}+\beta_{7} \log \mathrm{Debt}_{\mathrm{it}}+$ $\beta_{8} \log$ Equity $_{\mathrm{it}}+\varepsilon_{\mathrm{it}}$

where $i=1,2, \ldots, N$ and $t=1,2, \ldots, T$. $\mathrm{N}$ is the total number of companies and $\mathrm{T}$ is the total number of periods.

The individual-specific intercept $u_{i t}$ controls for any combination of cross-section invariant variables that have been omitted (unobserved effects), knowingly or otherwise, from the regression model. Performance ${ }_{i t}$ is one of the four commonly used performance variables considered, including stock return, Tobin's q, ROA and ROE. The INED ratio (INEDR) is the main independent variable considered. The other variables (board size, debt to equity ratio, total asset book value, market value of shares, total debt values and total equity values) are control variables.

\section{Sample Selection and Data Collection Procedures}

The sample consists of Hong Kong firms incorporated and listed on the SEHK. A panel dataset is used, covering 2000-2011 inclusively. Therefore, the data cover a period before and after the mandate made at the end of the year 2004 requiring the presence of three INEDs on boards in Hong Kong. The minimum 
number of years of data for each firm is seven years with a maximum of twelve years. The mean is 11.4 years, generating a balanced panel dataset. After adjustments, the dataset provides 10,524 firm-year observations from 827 companies. The data were taken from a number of different sources. Company annual reports in the HKEx provided details for non-executive director representation. The reports also provided information related to board and institutional ownership. All of the other performance data and control variables were taken from DataStream.

Variable Definitions

All of the variables are identified and defined in the following table.

TABLE 1

VARIABLE DEFINITIONS

\begin{tabular}{|l||l||}
\hline \multicolumn{1}{|l||}{ Variable } & Definitions \\
\hline \hline Year & Year of the data \\
\hline \hline FA & Firm age of listing \\
\hline \hline STRN & Share price \\
\hline \hline T & Stock return \\
\hline \hline TC & Tobin's q \\
\hline \hline INEDR & Ratio of independent directors \\
\hline \hline INEDN & Number of independent directors \\
\hline \hline BS & Board size \\
\hline \hline ROE & Return on equity \\
\hline \hline ROA & Return on asset \\
\hline \hline DE & Debt to equity ratio \\
\hline \hline Mkt & Market value of shares \\
\hline \hline TA & Total asset book value \\
\hline \hline Debt & Total debt book value \\
\hline Equity & Total equity book value \\
\hline \hline & $\begin{array}{l}\text { Percentage change of stock return index (with capital gains and reinvestment of } \\
\text { dividends) }\end{array}$ \\
\hline \hline RIp & Total asset book value, logarithm \\
\hline \hline logTA & Market value of shares, logarithm \\
\hline \hline logMkt & Total debt book value, logarithm \\
\hline \hline logDebt & Total equity book value, logarithm \\
\hline
\end{tabular}

\section{Grouping and Classification of Companies}

In this study, 877 companies covering 2000-2011 available in the database were considered, including 151 Chinese companies and 726 non-Chinese companies.

The total number of companies in the panel was extracted from different databases (mainly DataStream with other information sources) during the research period. All the companies are divided into two main groups/categories according to their Chinese/non-Chinese status. The Chinese companies are further divided into the $\mathrm{H}$-share and red chip companies. These Chinese companies can be further classified into main board and GEM categories. The non-Chinese companies are further divided into family- and nonfamily-controlled firms. Figure 2 illustrates the grouping arrangements.

Since there are many different types of firms in the total population, the hypotheses must test whether INEDs influence firm performance across different segments. SOEs, family-controlled businesses and other 
companies in Hong Kong (including HSI constituent and GEM companies) can differ drastically; therefore, hypotheses were posed for each of these classifications or groups of companies. In this paper, we have proposed the following hypotheses for all companies in Hong Kong and the HSI constituent companies; the other grouping will be discussed in future papers:

1. The first Hypothesis (H1) applies to all Hong Kong companies in general.

The Null Hypothesis (H0): Increasing the number of INEDs has no effect on firm performance. The Alternative Hypothesis (HA): Increasing the number of INEDs affects firm performance These hypotheses follow the understanding that the overall effects of the relationship between INEDs and firm performance are inconclusive based on the literature review

2. The second Hypothesis (H2) applies to all HSI constituent companies in Hong Kong in general. The Null Hypothesis (H0): Increasing the number of INEDs has positive effects on the performance of HSI constituent companies.

The Alternative Hypothesis (HA): Increasing the number of INEDs has no effect on the performance of HSI constituent companies.

As HSI constituent companies are leading companies, the better their board compositions, the more likely increasing the number of INEDs is to positively benefit their performance.

All listed companies can be further classified into main board and GEM categories in Figure 3. 
FIGURE 2

DIFFERENT TYPES OF COMPANIES LISTED IN HONG KONG: CLASSIFICATION I

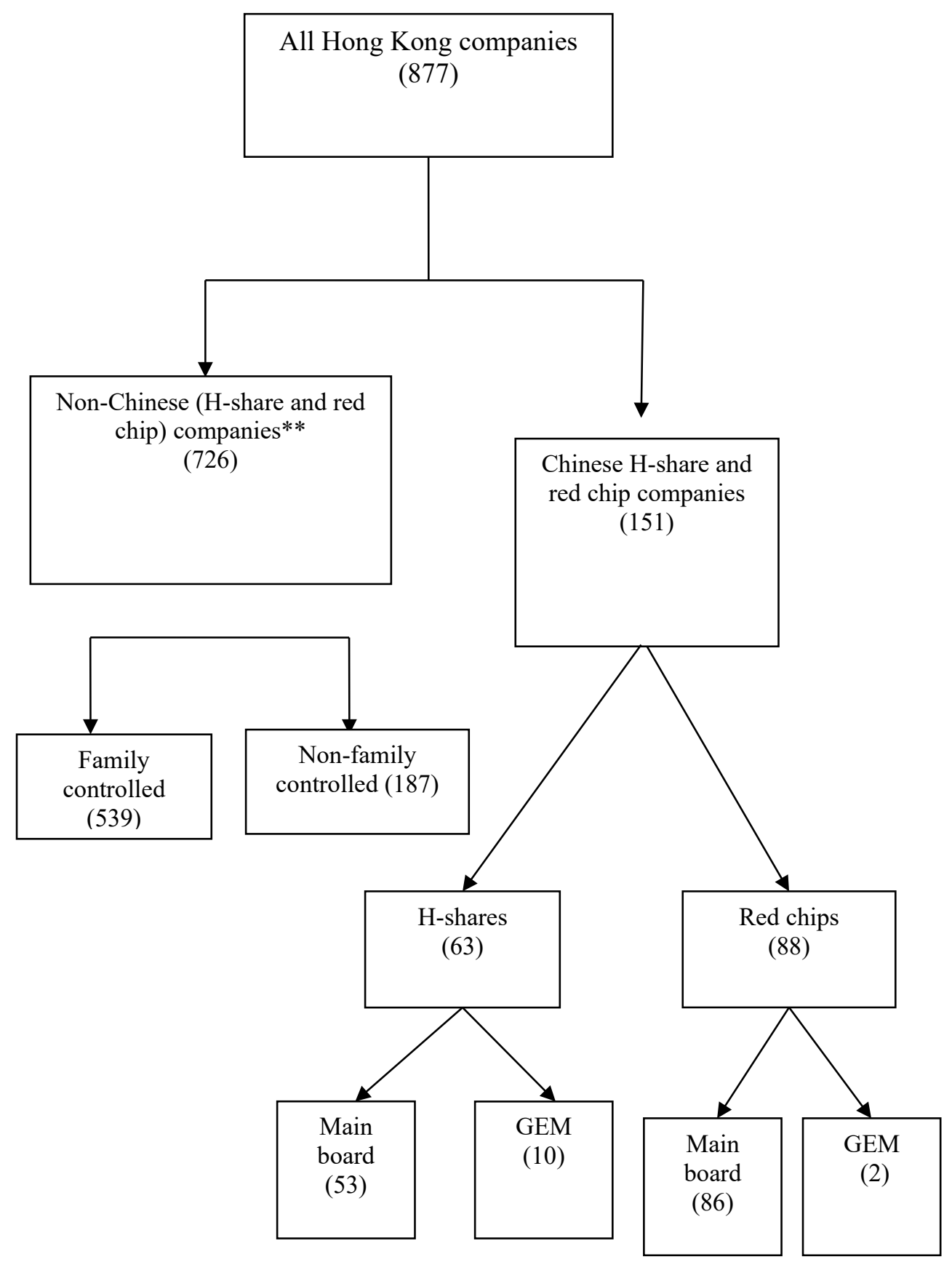


FIGURE 3

DIFFERENT TYPES OF COMPANIES LISTED IN HONG KONG: CLASSIFICATION II

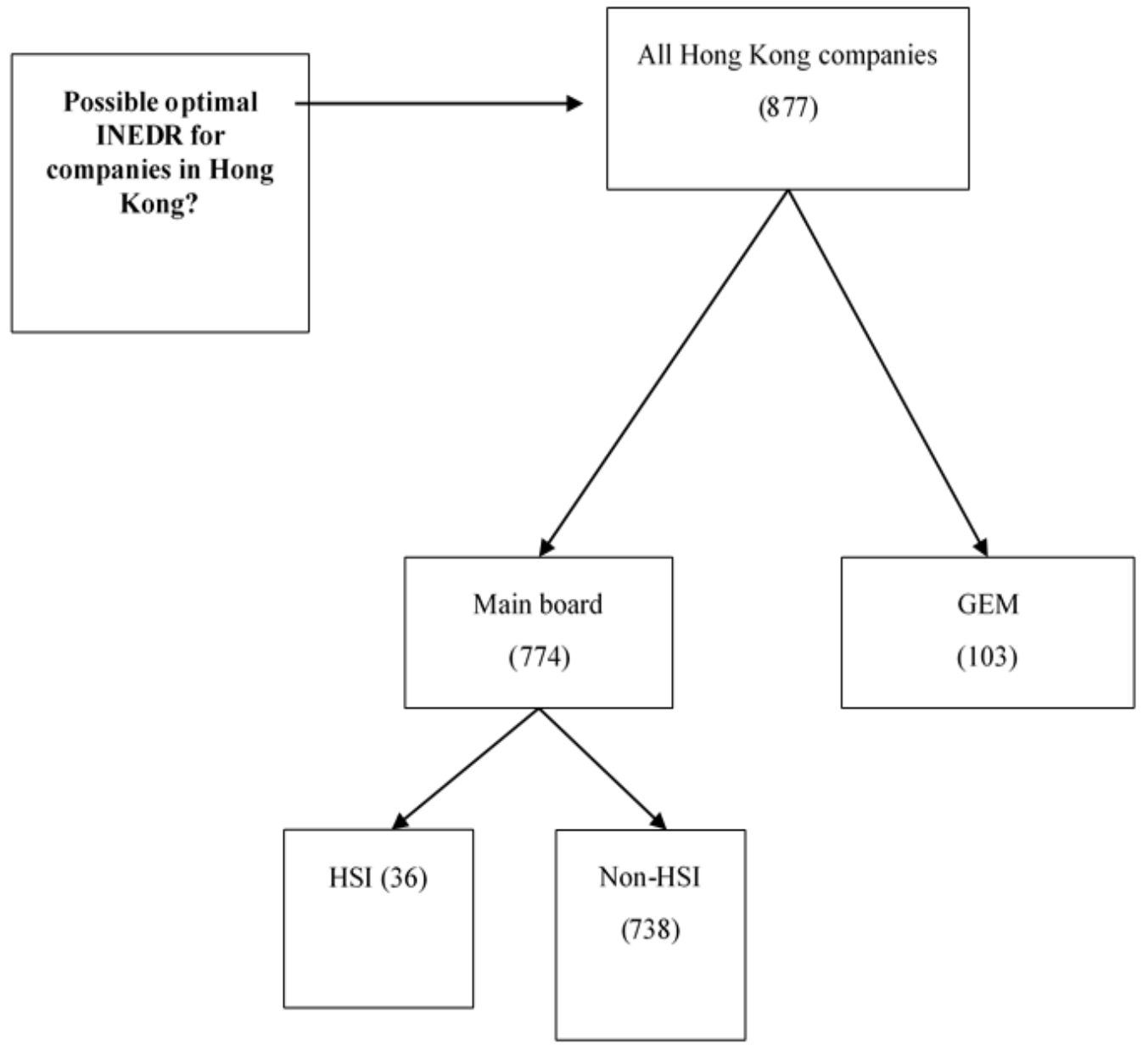

\section{RESULTS}

\section{Listed Companies in Hong Kong}

As shown in Figures 2 and 3, there are 877 companies from the research database available for analysis beginning in the first year under consideration. Table 2 shows the correlations of the variables for all of the Hong Kong companies. 


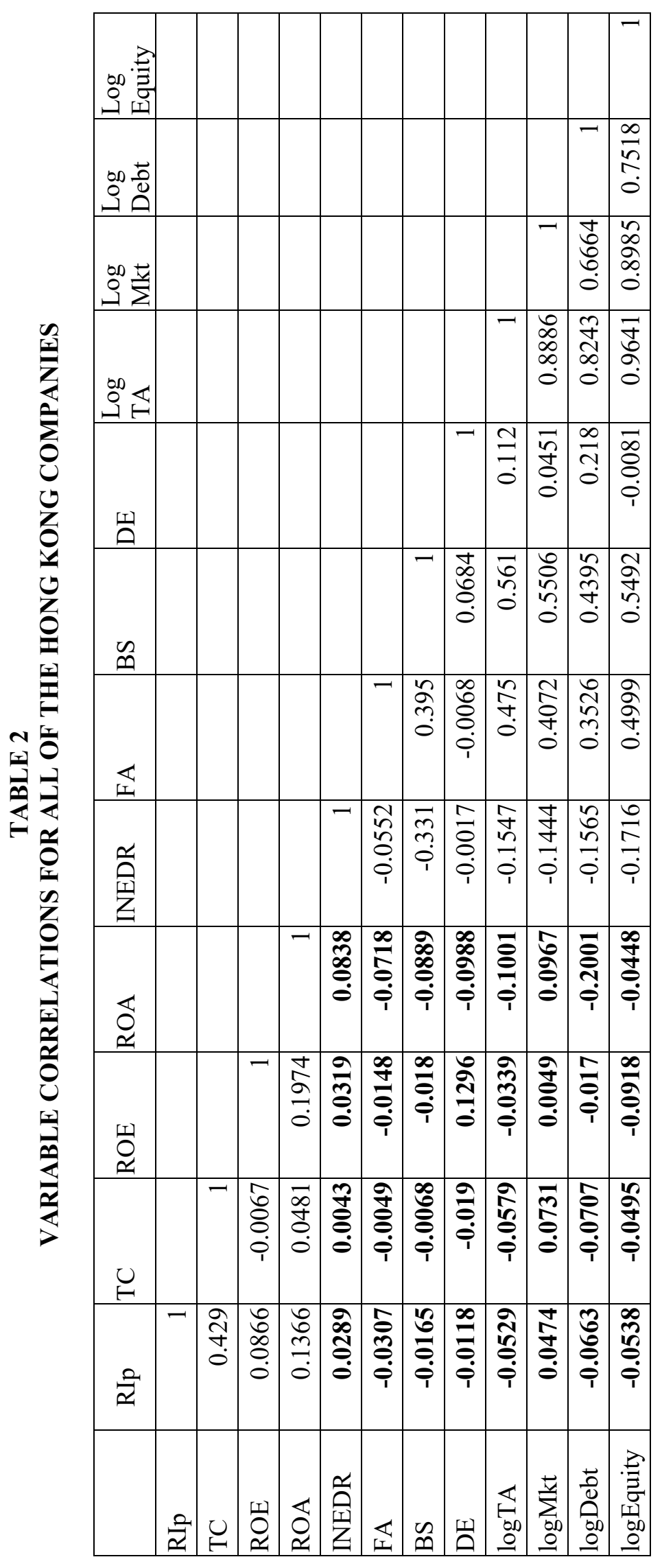

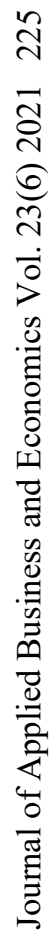


All of the correlations of the performance variables with INEDR are positive, ranging from $0.4 \%$ (TC) to $8.4 \%$ (ROA). The correlations of the performance variables with board size are negative. However, when they are included in the panel regressions under different segments, only a few of the effects are positive and significant and the rest are insignificant. The correlations of the performance variables with firm age, firm size and debt ratio are negative in general.

Following the statistical analysis procedures for choosing panel data model, a Breuch-Pagan LM test is conducted to determine whether the random effects panel regression or pooled OLS should be used. If the pooled OLS should not be used, an additional F-test is conducted to determine whether the fixed effects model should be fitted. According to analysis, the fixed effect models for the four performance variables are fitted. Table 3 shows the results.

Discussion of Results (Fixed Effects Model)

TABLE 3

FIXED EFFECTS MODEL RESULTS FOR ALL HONG KONG COMPANIES

\begin{tabular}{|c|c|c|c|c|}
\hline & \multicolumn{4}{|c|}{ Dependent variables } \\
\hline & $\begin{array}{l}\text { Stock return with } \\
\text { reinvestment of } \\
\text { dividend }(\mathrm{RI})\end{array}$ & $\begin{array}{l}\text { Change in } \\
\text { Tobin's q } \\
\text { (TC) }\end{array}$ & $\begin{array}{c}\text { Return on equity } \\
\quad(\mathrm{ROE})\end{array}$ & $\begin{array}{l}\text { Return on asset } \\
\quad(\text { ROA })\end{array}$ \\
\hline \multirow[t]{2}{*}{$\begin{array}{l}\text { Ratio of independent directors } \\
\text { (INEDR) }\end{array}$} & 0.078 & & 0.024 & \\
\hline & $(0.478)$ & $(0.027)$ & $(0.153)$ & $(0.000)$ \\
\hline \multirow[t]{2}{*}{ Firm age (FA) } & $-0.027 * * *$ & -0.002 & -0.001 & $-0.006 * * *$ \\
\hline & $(0.000)$ & $(0.391)$ & $(0.303)$ & $(0.000)$ \\
\hline \multirow[t]{2}{*}{ Leverage ratio (DE) } & 0.000 & 0.000 & $0.000 * *$ & 0.000 \\
\hline & $(0.039)$ & $(0.598)$ & $(0.033)$ & \\
\hline \multirow[t]{2}{*}{ Board size (BS) } & $0.020 * * *$ & 0.000 & 0.001 & 0.000 \\
\hline & $(0.001)$ & $(0.874)$ & $(0.336)$ & $(0.963)$ \\
\hline \multirow[t]{2}{*}{$\begin{array}{l}\text { Book value of equity, } \\
\text { logarithm (logEquity) }\end{array}$} & $-0.078 * *$ & $-0.093 * * *$ & $-0.122 * * *$ & $0.058 * * *$ \\
\hline & $(0.060)$ & $(0.000)$ & $(0.000)$ & $(0.000)$ \\
\hline \multirow[t]{2}{*}{$\begin{array}{l}\text { Book value of debt, logarithm } \\
(\operatorname{logDebt})\end{array}$} & 0.000 & 0.011 & -0.005 & -0.010 \\
\hline & $(0.974)$ & $(0.055)$ & $(0.003)$ & $(0.000)$ \\
\hline
\end{tabular}




\begin{tabular}{|l|r|r|r|r|}
\hline $\begin{array}{l}\text { Book value of total assets, } \\
\text { logarithm (logTA) }\end{array}$ & $-0.459 * * *$ & $-0.268^{* * *}$ & $0.073 * * *$ & -0.009 \\
\hline $\begin{array}{l}\text { Market value of equity, } \\
\text { logarithm (logMkt) }\end{array}$ & $0.740 * * *$ & $0.333^{* * *}$ & $0.055^{* * *}$ & $0.022 * * *$ \\
& $(0.000)$ & $(0.000)$ & $(0.000)$ & $(0.000)$ \\
\hline
\end{tabular}

$(* * *, * *$ and $*$ represent significance at the $1 \%, 5 \%$ and $10 \%$ levels, respectively)

The effects of INEDs on firm performance are inconsistent or mixed across all of the Hong Kong companies. Only one of the three positive performance values is significant (ROA), and one effect is negative and significant (Tobin's q). The results are supported by the finding that board independence has no effect on improved firm performance (Bhagat \& Black, 2002; Dulewicz \& Herbert, 2004). However, the connection between board independence and firm performance is prone to scepticism, as poor performance may cause an increase in board independence (B. E. Hermalin \& Weisbach, 2003). Whether those nonsignificant effects are correct in general must be tested and verified by dividing all companies into different groups or sectors according to their different natures for further analysis before a universal conclusion for the companies in Hong Kong can be reached.

Several studies have indicated that the effectiveness of outside directors or INEDs depends on the information environment and that a higher proportion of INEDs is associated with more effective monitoring and constrained earnings management. This suggests that a higher proportion of INEDs on corporate boards is likely to deter managers from manipulating reported earnings. Thus, the quality of the reported earnings of firms with higher proportions of INEDs is expected to be high.

INED effectiveness may account for the inconsistent results related to the effects of independent directors on the performance of all Hong Kong companies.

\section{Discussion of Results (HSI) (Fixed Effects Model)}

Analysis of the panel regression results follows the same methodology used in the previous section. 
TABLE 4

FIXED EFFECTS MODEL RESULTS FOR HSI CONSTITUENTS IN HONG KONG

\begin{tabular}{|c|c|c|c|c|}
\hline & \multicolumn{4}{|c|}{ Dependent variables } \\
\hline & $\begin{array}{c}\text { Stock return with } \\
\text { reinvestment of } \\
\text { dividend }(\mathrm{RI})\end{array}$ & $\begin{array}{l}\text { Change in } \\
\text { Tobin's q }\end{array}$ & $\begin{array}{l}\text { Return on } \\
\text { equity (ROE) }\end{array}$ & $\begin{array}{c}\text { Return on } \\
\text { assets (ROA) }\end{array}$ \\
\hline \multirow{2}{*}{$\begin{array}{l}\text { Ratio of independent directors } \\
\text { (INEDR) }\end{array}$} & 0.004 & -0.287 & 0.023 & 0.011 \\
\hline & $(0.994)$ & $(0.252)$ & $(0.562)$ & $(0.747)$ \\
\hline \multirow[t]{2}{*}{ Firm age (FA) } & $0.060 * * *$ & $0.045^{* * *}$ & 0.000 & 0.002 \\
\hline & $(0.002)$ & $(0.000)$ & $(0.802)$ & $(0.155)$ \\
\hline \multirow[t]{2}{*}{ Leverage ratio (DE) } & -0.001 & -0.001 & 0.000 & 0.000 \\
\hline & $(0.574)$ & $(0.450)$ & $(0.858)$ & $(0.725)$ \\
\hline \multirow[t]{2}{*}{ Board size (BS) } & 0.017 & $(0.003)$ & $0.003 * *$ & 0.000 \\
\hline & $(0.202)$ & $(0.741)$ & $(0.030)$ & $(0.838)$ \\
\hline \multirow{2}{*}{$\begin{array}{l}\text { Book value of equity, logarithm } \\
\text { (logEquity) }\end{array}$} & $-1.030 * * *$ & $-0.640 * * *$ & 0.008 & $0.065 * * *$ \\
\hline & $(0.000)$ & $(0.000)$ & $(0.766)$ & $(0.004)$ \\
\hline \multirow{2}{*}{$\begin{array}{l}\text { Book value of debt, logarithm } \\
\text { (logDebt) }\end{array}$} & 0.046 & -0.012 & -0.008 & $-0.010 * *$ \\
\hline & $(0.542)$ & $(0.762)$ & $(0.227)$ & $(0.085)$ \\
\hline \multirow{2}{*}{$\begin{array}{l}\text { Book value of total assets, logarithm } \\
(\log \text { TA) }\end{array}$} & -0.372 & -0.174 & -0.033 & $-0.093 * * *$ \\
\hline & $(0.159)$ & $(0.232)$ & $(0.186)$ & $(0.000)$ \\
\hline \multirow{2}{*}{$\begin{array}{l}\text { Market value of equity, logarithm } \\
(\operatorname{logMkt})\end{array}$} & $0.765 * * *$ & $0.433 * * *$ & $0.049 * * *$ & $0.035 * * *$ \\
\hline & $(0.000)$ & $(0.000)$ & $(0.000)$ & $(0.000)$ \\
\hline
\end{tabular}

$(* * *, * *$ and $*$ represent significance at the $1 \%, 5 \%$ and $10 \%$ levels, respectively) 
The effects of increasing the number of INEDs on the firm performance variables are insignificant and inconsistent, with results comparable with those of all Hong Kong companies in the previous section. However, they are generally positive, and the magnitude and significance of the effects of INEDR decrease, probably due to the assumption that HSI constituent companies are leaders or the best in their fields and are assumed to have better corporate governance structures and controls. Hence, the influence of INEDs on firm performance should not be the same across all of the companies in Hong Kong in general. The index also includes 16 family businesses (44.4\%) and 14 China SOE/red chip companies (38.9\%). Again, they are probably the leaders in the field, and their governance is hence assumed to perform much better than that of other similar companies in the same industry.

As a result, the increasing effects of INEDs on the performance of these HSI companies are insignificant.

\section{CONCLUSION}

Given the stringent INED requirements applied to SEHK-listed companies over the last 20 years, whether increased INED presence is beneficial was investigated for the listed companies in Hong Kong. INEDs have different effects on firm performance across different segments in Hong Kong. The effects are inconsistent across companies in Hong Kong and insignificant for HSI constituent companies in general. This observation is supported by some researches that find no connection between board independence and firm performance.

However, increasing the number of INEDs may have different effects on firm performance in the growth enterprise market, $\mathrm{H}$-share companies in China and red chip companies in China. The effects are also subject to test for family-controlled firms and non-family-controlled firms. Therefore, the policy of increasing INED presence should be tailored to different market segments based on agency and resource dependence theory.

This study focuses mainly on independent directors and does not purport to be an exhaustive study of all matters pertaining to the effects of board composition on firm performance or corporate governance and its related topics. There are many other information-related areas of research potential not covered in this study. We will continue to investigate the effects of INED on performance of companies in other segments such as GEM board companies, Chinese and family-controlled firms in future.

In summary, corporate governance is always subject to review and reform to help direct business more effectively in different regions around the world. The OECD defines corporate governance as follows: 'Corporate governance is about the way in which boards oversee the running of a company by its managers, and how board members are in turn accountable to shareholders and the company.' Hence, the most important element of corporate governance is the board of the firm. A better understanding of the nature and functions of board composition in terms of aspects such as transparency and information costs in addition to the advantages of cross-listing and independent director effectiveness would produce better boards and improve firm performance. 


\section{REFERENCES}

Anderson, A., \& Gupta, P.P. (2009). A cross-country comparison of corporate governance and firm performance: Do financial structure and the legal system matter? Journal of Contemporary Accounting and Economics, 5(2), 61-79.

Barnhart, S.W., \& Rosenstein, S. (1998). Board composition, managerial ownership, and firm performance: An empirical analysis. Financial Review, 33(4), 1.

Berger, A.N., \& Bonaccorsi di Patti, E. (2006). Capital structure and firm performance: A new approach to testing agency theory and an application to the banking industry. Journal of Banking \& Finance, 30(4), 1065-1102.

Bhagat, S., \& Black, B. (2002). The Non-Correlation Between Board Independence and Long-Term Firm Performance. Journal of Corporation Law, 27(2), 231.

Brown, L., \& Caylor, M. (2009). Corporate governance and firm operating performance. Review of Quantitative Finance and Accounting, 32(2), 129-144.

Chen, C.J.P., \& Jaggi, B. (2000). Association between independent non-executive directors, family control and financial disclosures in Hong Kong. Journal of Accounting \& Public Policy, 19(4/5), 285-310.

Cheung, Y-L., Thomas Connelly, J., Limpaphayom, P., \& Zhou, L. (2007). Do Investors Really Value Corporate Governance? Evidence from the Hong Kong Market. Journal of International Financial Management \& Accounting, 18(2), 86-122.

Chin-Jung, L., \& Ming-Je, T. (2007). Where is Independent Director Efficacy? Corporate Governance: An International Review, 15(4), 636-643.

Choi, J.J., Park, S.W., \& Yoo, S.S. (2007). The Value of Outside Directors: Evidence from Corporate Governance Reform in Korea. Journal of Financial \& Quantitative Analysis, 42(4), 941-962.

Cordeiro, J., He, L., Conyon, M., \& Shaw, T. (2013). Informativeness of performance measures and Chinese executive compensation. Asia Pacific Journal of Management, 30(4), 1031-1058.

Dalton, D.R., Daily, C.M., Johnson, J.L., \& Ellstrand, A.E. (1999). Number of Directors and Financial Performance: A Meta-Analysis. The Academy of Management Journal, 42(6), 674-686.

DeMott, D.A. (2008). Guests at the Table?: Independent Directors in Family-Influenced Public Companies. Journal of Corporation Law, 33(4), 819-863.

Doidge, C., Andrew Karolyi, G., \& Stulz, R.M. (2007). Why do countries matter so much for corporate governance? Journal of Financial Economics, 86(1), 1-39.

Dong-Sung, C., \& Kim, J. (2007). Outside Directors, Ownership Structure and Firm Profitability in Korea. Corporate Governance: An International Review, 15(2), 239-250.

Dougherty, C. (2011). Introduction to Econometrics. OUP Oxford.

Duchin, R., Matsusaka, J.G., \& Ozbas, O. (2010). When are outside directors effective? Journal of Financial Economics, 96(2), 195-214.

Dulewicz, V., \& Herbert, P. (2004). Does the Composition and Practice of Boards of Directors Bear Any Relationship to the Performance of their Companies? Corporate Governance: An International Review, 12(3), 263-280.

Erkens, D.H., Hung, M., \& Matos, P. (2012). Corporate governance in the 2007-2008 financial crisis: Evidence from financial institutions worldwide. Journal of Corporate Finance, 18(2), 389-411.

Gapenski, L.C. (1996). Using MVA and EVA to measure financial performance. HFM (Healthcare Financial Management), 50(3), 56.

Gordon, J.N. (2008). The Rise of Independent Directors. Directorship, 34(1), 58-63.

Greene, W.H. (2003). Econometric analysis (Vol. 5). Prentice hall.

Hermalin, B.E., \& Weisbach, M.S. (2003, April). Boards of Directors as an Endogenously Determined Institution: A Survey of the Economic Literature. Economic Policy Review, 9(1).

HKEX. (2013b). Listing Rules (Main Board) updated 1 Jan 2013. HKEX website.

Hsiao, C. (2003). Analysis of Panel Data. Cambridge University Press. 
Jackling, B., \& Johl, S. (2009). Board Structure and Firm Performance: Evidence from India's Top Companies. Corporate Governance: An International Review, 17(4), 492-509.

Jaggi, B., Leung, S., \& Gul, F. (2009). Family control, board independence and earnings management: Evidence based on Hong Kong firms. Journal of Accounting and Public Policy, 28(4), 281-300.

Kirkpatrick, G. (2009). Corporate Governance Lessons from the Financial Crisis. OECD Journal: Financial Market Trends, 2009(1), 61-87.

Mitton, T. (2002). A cross-firm analysis of the impact of corporate governance on the East Asian financial crisis. Journal of Financial Economics, 64(2), 215-241.

Palepu, K.G., Healey, P.M., Bernard, V.L., \& Peek, E. (2007). Business Analysis and Valuation (IFRS edition). Thomson.

Rabe-Hesketh, S., \& Skrondal, A. (2008). Multilevel and Longitudinal Modeling Using Stata (Second Edition). Stata Press.

Rabe-Hesketh, S., \& Skrondal, A. (2012). Multilevel and Longitudinal Modeling Using Stata: Continuous Responses (Third Edition). Stata Press.

Smith, B.F., \& Amoako-Adu, B. (1999). Management succession and financial performance of family controlled firms. Journal of Corporate Finance, 5(4), 341-368.

Tobin, J. (1969). A general equilibrium approach to monetary theory. Journal of Money, Credit and Banking, 1(1), 15-29.

Wooldridge, J.M. (2010). Econometric Analysis of Cross Section and Panel Data. MIT Press.

Xiao, J.Z., Dahya, J., \& Lin, Z. (2004). A Grounded Theory Exposition of the Role of the Supervisory Board in China*. British Journal of Management, 15(1), 39-55.

Yermack, D. (1996). Higher market valuation of companies with a small board of directors. Journal of Financial Economics, 40(2), 185-211. 